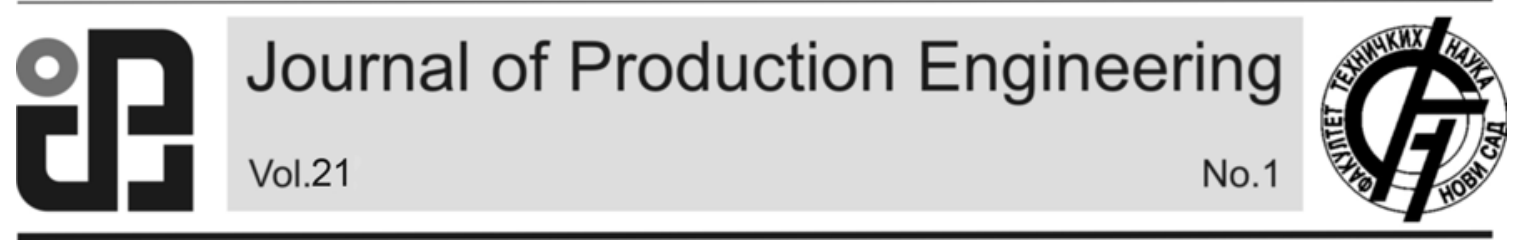

JPE (2018) Vol.21 (1)

Mirjanić, V., Mirjanić, Đ., Čupić, S., Ješić. D.

Original Scientific Paper

\title{
A COMPARASION OF BRACKET DEBONDING FORCES BETWEEN THE TWO ADHESIVES: CON TEC LC AND CON TEC DUO
}

Received: 07 November 2017 / Accepted: 28 March 2018

\begin{abstract}
Fixed technique for applying brackets would be impossible without using adhesives for their fixation to the tooth enamel. However, the use of adhesives entails a number of problems which are a consequence of their imperfection, besides the fact that they have been actually applied for a number of decades already. The paper will analyze the debonding force values for bracket-tooth interface by using Con Tec LC and, Con Tec Duo. For comparative analysis of the strength of bracket-tooth interface, with the application of different types of adhesives, 80 extracted teeth of the frontal region were used (central, lateral incisor teeth and canines of the upper and lower tooth arch). For the debonding process of applied orthodontics brackets, single-axial Stretch system for examination of tissues was applied to determine the value of the force necessary to separate the bracket from tooth surface, i.e. it was used to test debonding force. The direction of the used force for debonding was under angle of 90 degrees to the vertical axis of the tooth. By comparison of mean values of the strength of interface among the tested groups, it was determined that the highest average value of bond strength was with the group of teeth with which Con Tec Duo was used, a little lower mean value was recorded with the use of Con Tec LC adhesive.
\end{abstract}

Key words: adhesives, orthodontic bracket, debonding, stretch system

Upoređivanje sila odlepljivanja podupirača zuba lepljenih pomoću dva lepila: Con Tec LC i Con Tec Duo. Tehnika fiksiranja zuba u protezi bila bi nemoguća bez upotrebe lepkova za njihovo fiksiranje na zubnu emajl. Međutim, upotreba lepkova podrazumeva niz problema koji su posledica njihove nesavršenosti, iako su u primeni već nekoliko decenija. Rad će analizirati vrijednosti sile odleplivanja sa površine zuba lepljenih pomoću Con Tec LC $i$ Con Tec Duo. Za komparativnu analizu jačine površine zuba, lepljenih pomoću različitih tipova lepkova korišćeno je 80 ekstrahovanih zuba prednjeg regiona (centralni, bočni zubi za i kanine gornjih i donjih zuba). Za proces odlepljivanja primenjenih ortodontskih podupirača primenjen je jedan aksijalni Stretch sistem za ispitivanje tkiva da bi se utvrdila vrednost sile koja je potrebna za odvajanje proteze sa površine zuba, tj. korišćena je za testiranje sile odlepljivanja. Pravac korišćene sile za odleplivanje je bio manji od ugla 90 stepeni do vertikalne osovine zuba. Poređenjem srednje vrednosti jačine interfejsa među ispitivanim grupama, utvrđeno je da je najviša prosečna vrednost jačine veze bila sa grupom zuba kod kojih je korišćen Con Tec Duo, pri čemu je zabeležena nešto niža srednja vrednost Con Tec LC lepka.

Ključne reči: lepkovi, ortodontski podupirači, odleplivanje, sistem za istezanje

\section{INTRODUCTION}

Orthodontics, as science and practice, has developed through its history depending on the development of biology, medicine and technique. Advancement of technique in general and the knowledge derived from it made possible the use of that information to design orthodontic devices with certain elements comprising orthodontic device itself: bracket, screws, wires, rubber cups for traction, rubber bands etc, with quite precisely defined characteristics required by the therapy, all of which makes work significantly easier and provides a safer therapy outcome $[1,2]$.

One of the problems encountered relatively frequently by an orthodontist in his everyday work while using the fixed technique is occurrence of failure of brackets fixed to the tooth by adhesive. This requires re-application of the bracket, implying a waste of time both for the patient and the therapist, and entails other consequences too. One of the consequences is that if the bracket fails for the second time, it is not advisable to adhere it for the third time.

Numerous studies of the material used for bonding brackets have been undertaken because of the reasons mentioned above. These materials differ both by their chemical composition, the curing method, sensitivity to moist environment during bonding of brackets etc., as well as by the existence of extensive correlative dependence between these elements. This additionally complicates the deriving of absolutely safe conclusions as to "which is the best adhesive agent for bonding brackets in every specific case", depending on the age of the patient etc.

Taking into account the importance of the mentioned problems and the views of these processes and phenomena that are frequently contradictory, we have chosen this study in order to exactly determine the difference between the various types of adhesives (bonding agents), in terms of their adhesiveness, the course and comfort during work, with an aim to precisely define the guidelines and operating instructions for specific types of adhesives.

Nowadays, based on extensive research, there is a 
belief that the strength of bracket-tooth interface within the range 3-7 MPa is satisfactory for the clinical work of an orthodontist [3-5], while other authors state a somewhat bigger range of values $2,8-10 \mathrm{MPa}$ [6-7], whereas, according to Newman [8] et al. an acceptable minimum of the bond strength with regards to etched enamel ranges between 6-8 $\mathrm{MPa}$. On the one hand, orthodontists require as safe (strong) adhesive bond as possible, thus decreasing the possibility of undesired separation of bracket (bracket failure) during the therapy; on the other hand a stronger enamel-adhesive bond increases the risk of damaging tooth enamel during debonding [9-11]. It is more fortunate a circumstance if during debonding bracket is separated from the adhesive, with adhesive remaining on the tooth, rather than a situation where adhesive is bonded more strongly to the bracket, thus, separating adhesive together with the bracket may entail damage of enamel if the enamel-adhesive bond is strong. In the former case it is better to carefully remove the remaining part of the adhesive on the tooth with hard polishing rubber cups, rather than with turbine and diamond drill. This enamel damage that occurs relatively frequently should be repaired according to certain generally accepted principles that apply to such cases and situations.

\section{MATERIALS AND METHODS}

80 extracted teeth of the frontal region (central, lateral incisors and molars of upper and lower dental arch) were used for comparative analysis of brackettooth bond strength for application of Con Tec LC and Con Tec Duo adhesives. The criteria for teeth selection for the study were the following: no caries on labial surface, no cracks of enamel that can be caused by the pressure of forceps during tooth extraction, no hypoplastic macroscopically visible areas, and no decalcification caused by any reason.

The common procedure of tooth preparation for bonding brackets (regardless of adhesive type) was in accordance with the procedure that most commonly used for in vitro studies [12-14]. The procedure consisted of storing the freshly extracted human teeth in a solution of $0.1 \%$ (weight/volume) thymol. Teeth were cleansed and polished. The procedure of bonding brackets to teeth was done only after finishing the preparation (Figure 1).

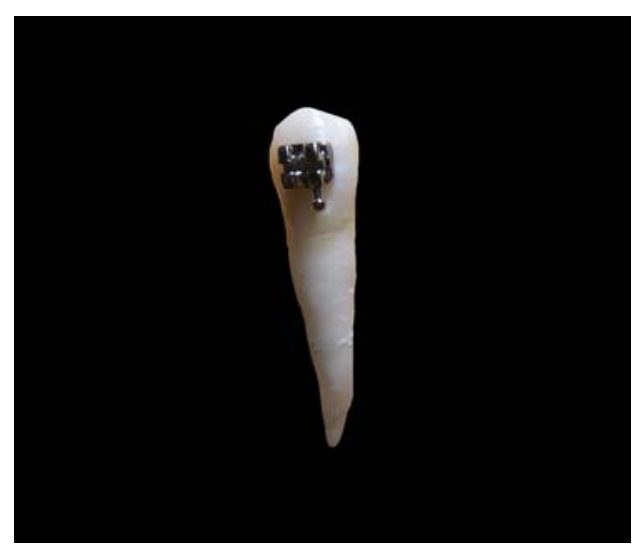

Fig. 1. Bracket bonded on a molar (prepared for experimental analysis).
During bonding brackets a protocol was applied determined by the requirements, i.e. manufacturer's instructions for each of the mentioned adhesives used in the study, i.e. the adhesives tested for the purpose of comparative analysis of bracket-tooth bond strength.

The study was done in vitro as this was done by many other investigators before [15-20] who tested certain characteristics of adhesive types in order to understand their specific properties, advantages and shortcomings compared to each other. An in vitro study of adhesives is more favorable compared to in vivo study, because it eliminates the factor of speed of work depending on researcher's dexterity, thus reducing the possibility of contamination of the working area with saliva, (which in turn reduces the adhesive strength of the bonding agent), having in mind that most adhesives are sensitive to moist as "one of the most common causes for bracket failure". Besides, laboratory study may indicate potential clinical success in certain conditions [21].

In order to avoid the influence of type of the bracket on bracket-tooth bond strength, the same type of metal bracket Discovery Slot 0,56 x 0,76 mm / $22 \times 30$ inch, Cuspid brackets with hooks was used with tested adhesives.

Con $\boldsymbol{T e c} \boldsymbol{L C}$ adhesives were used with the first group, in which curing was done by chemical activation, while in the second group Con Tec Duo adhesives were used which are chemically and lightcured.

The process of debonding of placed orthodontic brackets aimed at determining the size of force necessary to separate the bracket from tooth surface was measured in the Centre for Bioengineering of Kragujevac University. For the purpose of this study, the Centre for Bioengineering modified its device, a single-axial Stretch system for tissue testing [22-23], so that a new sensor for force of $300 \mathrm{~N}$ was mounted and used to test the force of separation of bracket from the tooth. The device on which testing was done is presented in Fig. 2, and the position of the tooth before starting debonding is presented in Fig. 3. The direction of application of debonding force was at the angle of 90 degrees at the vertical axis of tooth.

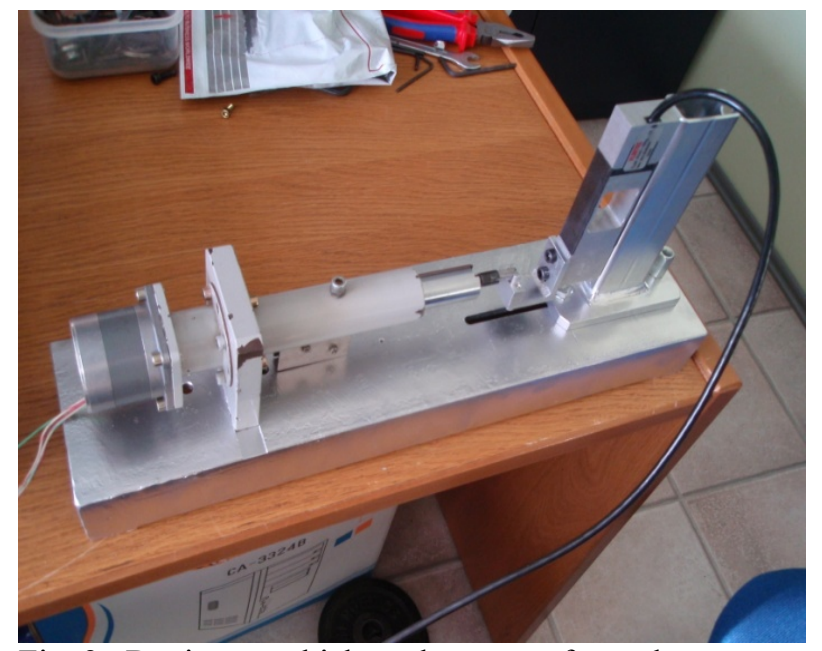

Fig. 2. Device on which study was performed ( Stretch system) 


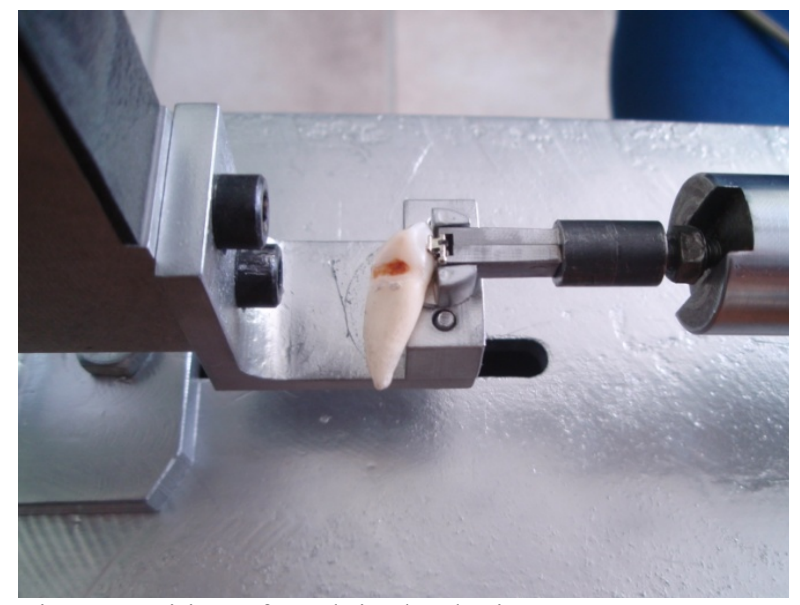

Fig. 3. Position of tooth in the device Stretchsystem, before starting debonding
Tensile force was accomplished at constant speed of $1 \mathrm{~mm} / \mathrm{min}$. The device automatically recorded the force with $0.3 \mathrm{~N}$ accuracy. The graph presents the forces in the function of time with 0.15 second intervals.

\section{RESULTS OF STUDY}

The values of debonding force on the upper and lower dental arches are presented in Table 1 for each tooth separately. The table presents the obtained values for all teeth within the groups (sample 40) tested with Con Tec LC and Con Tec Duo adhesives, whereas Table 2 presents the results of statistical analysis of debonding force for adhesive Con Tec LC and Table 3 the results for adhesive Con Tec Duo.

\begin{tabular}{|c|c|c|c|c|c|c|c|}
\hline $\begin{array}{l}\text { ConTec } \\
\text { LC }\end{array}$ & $\begin{array}{l}\text { Debonding force } \\
(N)\end{array}$ & $\begin{array}{l}\text { Tooth } \\
\text { arch }\end{array}$ & $\begin{array}{c}\text { Type of } \\
\text { tooth }\end{array}$ & $\begin{array}{c}\text { ConTec } \\
\text { Duo }\end{array}$ & $\begin{array}{l}\text { Debonding force } \\
(N)\end{array}$ & $\begin{array}{l}\text { Tooth } \\
\text { arch }\end{array}$ & $\begin{array}{l}\text { Type of } \\
\text { tooth }\end{array}$ \\
\hline 18. & 42,43 & $\mathrm{~L}$ & 1,2 & 8. & 48,78 & $\mathrm{~L}$ & 1,2 \\
\hline 8. & 42,52 & $\mathrm{~L}$ & 1,2 & 18. & 48,95 & $\mathrm{~L}$ & 1,2 \\
\hline 28. & 42,61 & $\mathrm{~L}$ & 1,2 & 38. & 51,86 & $\mathrm{~L}$ & 1,2 \\
\hline 38. & 42,91 & $\mathrm{~L}$ & 1,2 & 13. & 55,45 & $\mathrm{~L}$ & 1,2 \\
\hline 3. & 49,03 & $\mathrm{~L}$ & 1,2 & 3. & 56,23 & $\mathrm{~L}$ & 1,2 \\
\hline 23. & 49,13 & $\mathrm{~L}$ & 1,2 & 28. & 56,32 & $\mathrm{~L}$ & 1,2 \\
\hline 33. & 49,81 & $\mathrm{~L}$ & 1,2 & 23. & 56,83 & $\mathrm{~L}$ & 1,2 \\
\hline 13. & 50,08 & $\mathrm{~L}$ & 1,2 & 17. & 58,73 & $\mathrm{~L}$ & 1,2 \\
\hline 17. & 54,89 & $\mathrm{~L}$ & 1,2 & 33. & 59,64 & $\mathrm{~L}$ & 1,2 \\
\hline 7. & 55,25 & $\mathrm{~L}$ & 1,2 & 15. & 60,78 & $\mathrm{~L}$ & 1,2 \\
\hline 27. & 55,28 & $\mathrm{~L}$ & 1,2 & 7. & 61,12 & $\mathrm{~L}$ & 1,2 \\
\hline 37. & 55,81 & $\mathrm{~L}$ & 1,2 & 27. & 61,12 & $\mathrm{~L}$ & 1,2 \\
\hline 15. & 57,96 & $\mathrm{~L}$ & 1,2 & 37. & 61,83 & $\mathrm{~L}$ & 1,2 \\
\hline 5. & 58,21 & $\mathrm{~L}$ & 1,2 & 5. & 63,27 & $\mathrm{~L}$ & 3 \\
\hline 25. & 58,46 & $\mathrm{~L}$ & 3 & 25. & 63,75 & $\mathrm{~L}$ & 3 \\
\hline 35. & 58,81 & $\mathrm{~L}$ & 3 & 35. & 68,52 & $\mathrm{~L}$ & 3 \\
\hline 22. & 63,73 & $\mathrm{~L}$ & 3 & 22. & 68,98 & $\mathrm{~L}$ & 3 \\
\hline 2. & 63,84 & $\mathrm{~L}$ & 3 & 2. & 70,08 & $\mathrm{~L}$ & 3 \\
\hline 12. & 64,18 & $\mathrm{~L}$ & 3 & 12. & 70,14 & $\mathrm{~L}$ & 3 \\
\hline 32. & 64,81 & $\mathrm{~L}$ & 3 & 32. & 71,47 & $\mathrm{~L}$ & 1,2 \\
\hline 30. & 82,98 & $\mathrm{U}$ & 2 & 20. & 90,89 & $\mathrm{U}$ & 2 \\
\hline 10. & 83,08 & $\mathrm{U}$ & 2 & 30. & 92,34 & $\mathrm{U}$ & 2 \\
\hline 40. & 83,11 & $\mathrm{U}$ & 2 & 10. & 94,09 & $\mathrm{U}$ & 2 \\
\hline 20. & 83,15 & $\mathrm{U}$ & 2 & 40. & 94,48 & $\mathrm{U}$ & 2 \\
\hline 6. & 90,49 & $\mathrm{U}$ & 2 & 26. & 98,79 & $\mathrm{U}$ & 2 \\
\hline 26. & 90,51 & $\mathrm{U}$ & 2 & 6. & 99,74 & $\mathrm{U}$ & 2 \\
\hline 36. & 90,59 & $\mathrm{U}$ & 2 & 36. & 99,87 & $\mathrm{U}$ & 2 \\
\hline 16. & 91,05 & $\mathrm{U}$ & 2 & 16. & 102,87 & $\mathrm{U}$ & 3 \\
\hline 9. & 104,11 & $\mathrm{U}$ & 3 & 9. & 111,78 & $\mathrm{U}$ & 3 \\
\hline 19. & 105,06 & $\mathrm{U}$ & 3 & 29. & 116,67 & $\mathrm{U}$ & 2 \\
\hline 29. & 105,13 & $\mathrm{U}$ & 3 & 39. & 116,67 & $\mathrm{U}$ & 3 \\
\hline 39. & 105,81 & $\mathrm{U}$ & 3 & 19. & 120,43 & $\mathrm{U}$ & 3 \\
\hline 14. & 113,98 & $\mathrm{U}$ & 3 & 24. & 124,25 & $\mathrm{U}$ & 3 \\
\hline 4. & 114,77 & $\mathrm{U}$ & 3 & 14. & 124,34 & $\mathrm{U}$ & 3 \\
\hline 24. & 114,96 & $\mathrm{U}$ & 1 & 34. & 127,43 & $\mathrm{U}$ & 1 \\
\hline 34. & 115,07 & $\mathrm{U}$ & 1 & 21. & 128,67 & $\mathrm{U}$ & 1 \\
\hline 11. & 117,13 & $\mathrm{U}$ & 1 & 31. & 128,69 & $\mathrm{U}$ & 1 \\
\hline 21. & 118,21 & $\mathrm{U}$ & 1 & 4. & 128,97 & $\mathrm{U}$ & 1 \\
\hline 1. & 118,32 & $\mathrm{U}$ & 1 & 1. & 130,12 & $\mathrm{U}$ & 1 \\
\hline 31. & 118,57 & $\mathrm{U}$ & 1 & 11. & 137,76 & $\mathrm{U}$ & 1 \\
\hline
\end{tabular}

Table 1. Debonding forces for upper and lower dental arches for Con Tec LC and Con Tec Duo adhesives 


\begin{tabular}{|c|c|c|c|}
\hline \multirow{2}{*}{$\begin{array}{c}\text { Descriptive parameter (Debonding force (N) - adhesive } \\
\text { ConTecLC) }\end{array}$} & Upper & Lower & \multirow{2}{*}{ Total } \\
\cline { 2 - 4 } & Dental arch & 20 & 40 \\
\hline N & 20 & 42,43 & 42,43 \\
\hline MIN & 82,98 & 64,81 & 118,57 \\
\hline MAX & 118,6 & 22,38 & 76,14 \\
\hline I & 35,59 & - & - \\
\hline Mo & - & 55,27 & 73,90 \\
\hline Me & 105,1 & 53,99 & 78,15 \\
\hline Xsr & 102,3 & 7,59 & 26,84 \\
\hline SD & 13,88 & 14,06 & 34,35 \\
\hline CV & 13,57 & & \\
\hline
\end{tabular}

Table 2. Results of statistical analysis of debonding force for adhesive ConTec LC

\begin{tabular}{|c|c|c|c|}
\hline \multirow{2}{*}{$\begin{array}{c}\text { Descriptive parameter (Debonding force (N) - adhesive } \\
\text { ConTec Duo) }\end{array}$} & \multicolumn{2}{|c|}{ Dental arch } & \multirow{2}{*}{ Total } \\
\cline { 2 - 3 } & Upper & Lower & \\
\hline N & 20 & 20 & 40 \\
\hline MIN & 90,89 & 48,78 & 48,78 \\
\hline MAX & 137,76 & 71,47 & 137,76 \\
\hline I & 46,87 & 22,69 & 88,98 \\
\hline Mo & 116,67 & 61,12 & 61,12 \\
\hline Me & 116,67 & 60,95 & 81,18 \\
\hline Xsr & 113,44 & 60,69 & 87,07 \\
\hline SD & 15,33 & 6,83 & 29,17 \\
\hline CV & 13,51 & 11,25 & 33,50 \\
\hline
\end{tabular}

Table 3. Results of statistical analysis of bond strength obtained with ConTec Duo adhesive

Table 4 presents comparative results of statistical analysis for debonding force with Con Tec LC and Con Tec Duo adhesives.

The obtained total results for debonding force of teeth of the upper and lower dental arch show that the biggest average value $X_{\mathrm{sr}}=87,07 \mathrm{~N}$ was obtained with the group of teeth in which Con Tec Duo adhesive was used for bonding brackets, whereas a somewhat lower average value $X_{\mathrm{sr}}=78,15 \mathrm{~N}$ was obtained with the group of teeth in which $C \boldsymbol{C o n} T e c \boldsymbol{L C}$ was used.

The results of testing of significance of differences by t-test show that there is no statistically significant difference between the mean values of debonding forces for brackets fixed with Con Tec LC and Con Tec Duo adhesives $(\boldsymbol{p}=0,158601)$.

\begin{tabular}{|c|c|c|}
\hline Analysed statistical elements for parameter F (debonding force) & ConTec LC & ConTec Duo \\
\hline N & 40 & 40 \\
\hline MIN & 42,43 & 48,78 \\
\hline MAX & 118,57 & 137,76 \\
\hline I & 76,14 & 88,98 \\
\hline Mo & & 61,12 \\
\hline Me & 73,90 & 81,18 \\
\hline Xsr & 78,15 & 87,07 \\
\hline SD & 26,84 & 29,17 \\
\hline CV & 34,35 & 33,50 \\
\hline
\end{tabular}

Table 4. Comparative results of statistical analysis for parameter F (debonding force) with tested adhesives - total results (summary for all tested teeth of the upper and lower tooth arch) 


\section{CONCLUSIONS}

Based on comparative analysis of the results of the debonding force with tested adhesives for fixing brackets to tooth enamel, the following conclusions may be derived:

Comparison of mean values of debonding forces between tested adhesives showed that the highest average value of debonding force was with the group of teeth in which the adhesive Con Tec Duo was used, whereas somewhat lower value was obtained by use of Con Tec $L C$ adhesive.

The results that gave a clear insight in the brackettooth bond strength achieved by the tested adhesives that are nowadays most commonly used in practice have the following clinical-theoretical implications.

If the degree of tooth dislocation is bigger, which requires higher activation of arch, i.e. stronger force to move the tooth, it is necessary to use the adhesive by which the strongest toot-bracket bond is achieved, in order to avoid undesirable failure of the bracket (Con Tec Duo).

If the degree of disruption of tooth position is smaller, adhesives that achieve a lower bracket-tooth bond may be used too (Con Tec LC).

\section{REFERENCES}

[1] Graber,T., Vanarsdall, R., Vig, K. Current Principles and Techniques. Elsvier Mossby, St Louis; 2005.

[2] Mirjanić V,Čupić S. Contemporary materials in orthodontics. Eleventh Annual Conference Yucomat /Biomaterials, Herceg Novi, August 31September 4,2009; P.S.E.21.

[3] Carstensen W. Clinical results after direct bonding of brackets using shorter etching times. Am J Orthod. 1986; 89:70-72.

[4] Wilthshire WA. Shear bond strength of a glass ionomer for direct bonding in orthodontics. Am J. Orthod Dentofacial Orthop 1994; 106:127-30.

[5] Keizer S, Ten Cate JM, Arends J. Direct bonding of orthodontic brackets. Am J Orthod Dentofac Orthop 1976; 69:318-27.

[6] Lopez JI. Retentive shear strenghts of various bonding attachment bases. Am J. Orthod Dentofac Orthop 1980; 77:669-78.

[7] Reynolds IR. A review of direct orthodontic bonding. Br J Orthod 1985; 2:171-8.

[8] Newman GV. First direct bonding in ortodontia. Am J. Orthod Dentofacial Orthop. 1992; 101:190192.

[9] Vilchis S, Jose R, Seigo Y, Noriyuki K. Shear bond strength of orthodontics brackets bonded with self-etching adhesives. Am J Orthod Dentofac Orthop. 2009; 136(3):425-430.

[10] Foster J A, Berzins D W, Bradley T G. Bond strength of an amorphous calcium phosphatecontaining orthodontic adhesive. Angle Orthodontist. 2008; 78(2):339-344.

[11] Bishara SE, Ortho D, Donsombat C, Ajlouni R, Laffoon JF. Comparison of the shear bond strength of 2 self-etch primer adhesive systems.
Am J Orthod Dentofacial Orthop. 2004; 125:348350.

[12] Bishara SE, Ortho D, Laffoon JF, Wold LV, Warron J. Effect of time on the shear bond strength of cyanoacrylate and composite orthodontic adhesives. Am J Orthod Dentofacial Orthop. 2002;121:297-300.

[13] Bishara SE, Salisman M, Laffoon JF, Warren J. Shear bond strength of a new high fluoride release glass ionomer adhesive. Angle Orthod. 2008; 78(1):125-128.

[14] Park SB, Son WS, Ko CC, Garcia-Godoy S, Park MG, Kim H, Kwon YH. Influence of flowable resin on the shear bond strength of orthodontic brackets. Dental Materials J. 2009; 28(6):730-734.

[15] Mitić V. Janošević M. Influence of application time of orthophosphoros acid on the orthodontic bracket-tooth bond strength. Uticaj vremena aplikacije ortofosforne kiseline na jačinu veze ortodontskih bravica na zub. Serbian Dental J. 2008; 55:23-33.

[16] Mitić V. Shear bond strength of orthodontic brackets bonded with GIC. Serbian Dental Journal. 2009; 56:117-12.

[17] Bishara SE, Soliman M. Laffoon JF, Warren J. Shear bod strength of a new high fluoride release glass ionomer adhesive. The Angle Orthodontists. 2007;78:125-8.

[18] Bishara SE, Otsby AW, Ajlouni R, Laffoon J, Warren J. A new premixed self-etch adhesive for bonding orthodontic brackets. Angle Orthod. 2008;78(6):1101-1004.

[19] Lifshitz AB, Cardenas M. A comparison between the shear bond strength of brackets bonded to glazed and deglazed porcelain surfaces with resinreinforced glass-ionomer cement and a bis-GMA resin adhesive. World J Orthod. 2006; 7(2):134137.

[20] Lowder PD, Foley T, Banting DW. Bond strength of 4 orthodontic adhesives used with a caries protective resin sealant. Am J Orthod Dentofacial Orthop. 2008; 134(2):291-295.

[21] Matasa CG. Do you really know the reins you use Bis GMA. Orthodontic Materials Insider 2000; 13(1): 5-8.

[22] Pantović SB, Rosić GL, Rosić MA, Radosavljević M, Kojić MR, Milovanović JR, Lučić AP, Radovanović MR, Zdravković VS. Advanced approach to biomechanical and functional tissue properties - new design of applied hardware and software. Medicus. 2006; 6(1):18-20.

[23] Rosić M, Pantović S, Ranković V, Obradović Z. Filipović N, Kojić M.Evaluation of dynamic response and biomechanical properties of isolated blood vessels. J Biochem Methods. 2008;70:966972.

Authors: V. Mirjanić, Đ. Mirjanić, S. Čupić, Department of Dentistry, Faculty of Medicine, University of Banja Luka, Republic of Srpska, B\&H, Dr Dušan Ješić, International technology Menagement Academy, Trg Dositeja Obradovica 7, 21000 Novi Sad, Serbia, Phone.: +381 21 445317,. E-mail: dusanjesic@hotmail.com 